\title{
De invloed van de fiscale wetge- ving op vermogensongelijkheid in Nederland
}

David Hwan en Jessica de Vries

SAMENVATTING De vermogensongelijkheid is in Nederland relatief hoog. Dit kan leiden tot verminderde economische groei, politieke onstabiliteit en verlies van vertrouwen in de politiek, wat mogelijk problemen voor economie en politiek oplevert. In deze bijdrage wordt gekeken naar het tegengaan van vermogensongelijkheid door middel van de fiscaliteit. Wij onderzoeken de verdelende werking van box 3 van de Wet Inkomstenbelasting 2001 en de bedrijfsopvolgingsregeling van de Successiewet 1956. Het forfaitaire systeem van box 3 beantwoordt noch aan de realiteit van rendementen noch aan het draagkrachtbeginsel, hetgeen vermogensongelijkheid versterkt. Juist het draagkrachtbeginsel is een moreel fundament in het Nederlandse belastingsysteem en hierop teruggrijpen is wenselijk. Alternatieven voor box 3 zijn een progressief tarief en eventueel een andere heffingsvorm. De bedrijfsopvolgingsfaciliteit discrimineert de facto naar topvermogens. Om die reden lijkt een kredietfaciliteit rechtvaardiger.

\section{RELEVANTIE VOOR DE PRAKTIJK In de fiscale praktijk voert de gecodificeerde} wettekst vanzelfsprekend de boventoon. Er ontstaat echter een hernieuwde tendens om fiscaliteit en morele rechtvaardigheid naast elkaar te leggen (Van Apeldoorn, Gribnau \& Verbeek, 2015, p. 10). In het licht van deze tendens accentueert dit artikel het belang van rechtvaardige grondslagen in de fiscale wetgeving. Deze grondslagen wijzen erop dat de fiscale wetgeving verandering behoeft teneinde de vermogensongelijkheid tegen te gaan. Dat box 3 in veel gevallen niet aan realiteit en draagkracht beantwoordt is problematisch. Met het oog op het reeds gepresenteerde Belastingplan 2016 verschaft dit artikel aansporing, inzichten en advies. Verder is al een tijd discussie over de de jure onrechtvaardigheid van de bedrijsopvolgingsregeling (verder: BOR) in het teken van gelijke behandeling. De literatuur zwijgt echter over de de facto denivellerende werking van de BOR. De relatie tussen de BOR en vermogensongelijkheid verdient verder onderzoek.

\section{Inleiding}

\subsection{Vermogensongelijkheid in Nederland en het probleem} Piketty (2014) omschrijft in zijn omvangrijke werk de problemen van stijgende vermogensongelijkheid. $\mathrm{He}-$ laas neemt hij Nederland niet onder de loep. Het vermogen in Nederland blijkt namelijk uit gegevens van het Centraal Bureau voor de Statistiek (CBS) en de Wetenschappelijke Raad voor het Regeringsbeleid (WRR) zeer scheef verdeeld. De WRR laat zien dat de top $10 \%$-vermogenden ruim meer dan de helft van het totale Nederlandse vermogen bezit (Kremer, Bovens, Schrijvers \& Went, 2014, p. 84). Het CBS zegt zelfs dat deze groep meer dan 60\% heeft (CBS, 2014, p. 72). De top $2 \%$ heeft ongeveer een derde van het geheel aan vermogen in handen. Deze top staat in schril contrast met het grootste gedeelte van Nederland, waarvan de onderste $60 \%$ slechts $1 \%$ van het vermogen bezit. Verschillende factoren spelen een rol bij de vermogensongelijkheid. De top-vermogenden hebben kunnen profiteren van de toenemende globalisatie en bijbehorende kapitaalmobiliteit, de hoge aandelen- en onroerende-zakenrendementen en algemene rendementen die groter zijn dan de economische groei. ${ }^{1}$ De onderste $60 \%$ vermogenden hebben echter veel negatieve vermogens en vermogens waarbij de bezittingen even hoog zijn als de schulden, resulterend in een vermogen van nihil. Al met al leidt de Nederlandse vermogensongelijkheid tot een relatief hoge Gini-coëfficiënt (ongelijkheidscoëfficiënt) van $0,8 .{ }^{2}$ Het omvangrijke pensioenstelsel in Nederland verzacht de vermogensongelijkheid enigszins. De 875 miljard euro aan pensioenen heeft weliswaar meer weg van inkomen dan vermogen, maar draagt de facto toch bij aan vermindering van vermogensongelijkheid op latere leeftijd (Van Bavel \& Salverda, 1999, p. 392; Broers, 2014, p. 88). 
De vermogensongelijkheid van Nederland is ten eerste problematisch omdat het sterke vermoeden bestaat dat ongelijkheid leidt tot een daling van economische groei. Zo toont de OESO aan dat een gemiddelde stijging van inkomensongelijkheid ad 0,3 Gini-punten de afgelopen twintig jaar heeft geleid tot een daling van economische groei ad 0,35 procentpunt per jaar over vijfentwintig gemeten landen. ${ }^{3}$ Deze negatieve correlatie is verklaarbaar. De sociale mobiliteit neemt af doordat lagere vermogensgroepen niet kunnen investeren in zichzelf of in een goede opleiding voor hun kinderen (Kremer et al., 2014, p. 90; Broers, 2014, p. 116). Met het oog op de versobering van de Nederlandse verzorgingsstaat is deze oorzaak extra relevant. Ten tweede ontstaan door economische machtsconcentratie kloven tussen rijk en arm, resulterend in politieke instabiliteit. De politieke instabiliteit doet het vertrouwen van (buitenlandse) investeerders dalen, hetgeen economische groei remt. Tot slot is ook politiek gezien de huidige vermogensongelijkheid problematisch (Solt, 2008, pp. 49, 57). Economische machtsconcentratie geeft bepaalde groepen de middelen om meer invloed uit te oefenen op politiek beleid. Tevens neemt door de kloof tussen arm en rijk het vertrouwen in de politiek af en uiteindelijk daalt de politieke participatie van de onderste vermogensbezitters. De geschetste problemen geven natuurlijk niet aan dat vermogensongelijkheid helemaal geen positieve bijdragen levert. Naast dat een mate van ongelijkheid onvermijdelijk is, geeft ongelijkheid een stimulans om hard te werken, en deze stimulans valt in ieder geval weg als iedereen gelijk wordt gesteld.

\subsection{Rol van de fiscale wetgeving}

Naast de algemene problemen van de vermogensongelijkheid in Nederland, is de centrale vraag hoe en waarom de fiscaliteit in dit geheel de vermogensongelijkheid tegen moet en kan gaan. Recentelijk lijkt een tendens te ontstaan meer te kijken naar fundamentele filosofische achtergronden van het belastingrecht. ${ }^{4}$ Wij ondersteunen die tendens, want het idee van de fiscaal econoom die zonder waardeoordelen slechts technische informatie levert voor besluitvorming is passé. Onderzocht wordt hoe onderdelen van het fiscale systeem momenteel het vermogen verdelen. De focus ligt op de forfaitaire werking van box 3 . Het forfaitair systeem beantwoordt niet aan zaken als draagkracht en realiteit, en lijkt vermogensongelijkheid te versterken. Draagkracht is juist een fundamenteel beginsel van het heffen van belasting, zo wordt filosofisch beargumenteerd. Daarna kijken wij naar de BOR in de Succsssiewet. Successierechten spelen immers een belangrijke verdelende rol: de enige per generatieovergang. ${ }^{5}$ Het is dan ook jammer dat de literatuur niet spreekt van de schijnbaar denivellerende werking van de BOR. De BOR lijkt een rechtvaardiger en doelmatiger alternatief te hebben, zo bepleiten wij.

\subsection{Opbouw artikel}

In paragraaf 2 wordt aan de hand van subparagraaf 2.1 uitgelegd wat de problemen zijn met het huidige forfaitaire rendement. Vervolgens grijpt subparagraaf 2.2 terug op het draagkrachtbeginsel als filosofisch fundament van belastingheffing. De subparagrafen 2.3 tot en met 2.5 schijnen licht op het nieuwe Belastingplan en wijzen op andere oplossingen voor de huidige vermogensongelijkheid. Paragraaf 2.6 bevat een kanttekening bij de oplossingen. Hierna snijdt paragraaf 3 een nieuw onderwerp aan, namelijk de BOR. De problemen van de BOR worden geschetst in subparagraaf 3.1 en in subparagrafen 3.2 en 3.3 wordt betoogd hoe en waarom de BOR moet worden aangepast. Paragraaf 4 concludeert de bevindingen van het artikel.

\section{Box 3 in de Wet IB}

\subsection{Probleem met het forfaitaire rendement}

Het forfaitaire rendement van box 3 is sinds invoering in 2001 onderhevig aan kritiek (Herreveld, 1999, p. 2; Boer \& Vording, 2015, p. 1). De kritiek dat het forfaitaire rendement ten onrechte niet aan de realiteit beantwoordt, heeft vaste vorm gekregen door empirie van de Commissie Van Dijkhuizen en het CPB. De Commissie toont aan dat sinds de invoering van box 3 gemiddeld gezien slechts een reëel rendement is behaald van 1,6\% (Commissie Van Dijkhuizen, 2013, p. 64). Daarnaast is relevant dat volgens het $\mathrm{CPB}$ de onderste $40 \%$ huishoudens in de vermogensverdeling uitsluitend spaarrekeningen hebben (Floor, Groot $\&$ Lejour, 2015, p. 9; Commissie Van Dijkhuizen, 2013, p. 59). Op deze spaarrekeningen is echter slechts een rendement van $0,5 \%$ behaald. De topvermogens hebben voornamelijk aandelen en onroerende zaken (Kremer et al., 2014, p. 86). De top $1 \%$ heeft op aandelen en panden tussen 2006 en 2012 rendementen gehaald van slechts $0,2 \%$ en $-0,3 \%$ respectievelijk. Box 3 lijkt prima facie dus de minder vermogenden te bevoordelen, maar dit is met inachtneming van de crisis in 2008. Op de langere termijn (1990-2012) is te zien dat spaarrekeningen slechts een (nominaal) rendement van 3,3\% hebben behaald, in tegenstelling tot panden met rendementen van $4,4 \%$ en aandelen met rendementen van $5,7 \%$ (Floor et al., 2015, p. 9). Duidelijk zichtbaar is dat de werking van box 3 met een fictief vastgesteld rendement niet beantwoordt aan de rendementsrealiteit. Op de langere termijn worden de lagere vermogenden met louter spaarrekeningen benadeeld en de hoge vermogens door hun structureel hoger rendement juist bevoordeeld.

Het kernprobleem van box 3 ligt echter dieper. De Commissie oppert om het forfaitaire rendement aan te passen aan de werkelijk behaalde rendementen, berekend als vijfjarengemiddelde voorafgaand aan het jaar van belasten. Dit is onzes inziens echter niet de op- 
lossing voor box 3 . Zowel de huishoudens onder het forfaitaire rendement als huishoudens erboven doen namelijk ter zake voor vermogensongelijkheid. Verschillen tussen de twee groepen resulteren in een relatief lagere belastingdruk voor degenen die structureel boven het fictief rendement liggen, en een relatief hoge belastingdruk voor degenen onder het forfait. Oftewel: een vast fictief rendement kan nooit beantwoorden aan draagkracht, omdat er altijd hogere en lagere rendementen zijn (Niessen, 2000, p. 9). Draagkracht is juist een van de fundamentele beginselen in onze inkomstenbelasting. Met het forfaitaire rendement van $4 \%$ en tevens een vlak tarief van $30 \%$ werkt het huidig systeem van box 3 echter degressief. Daar komt bij dat hogere vermogens nog door hun omvangrijke middelen meer risico kunnen nemen, hetgeen ook resulteert in hogere rendementen en een lagere effectieve belastingdruk (Piketty, 2014, pp. 430-431). Daarentegen is beargumenteerbaar dat box 3 op macroniveau wel nivellerend werkt: $4 \%$ van $€ 1.000 .000$ is immers meer dan $4 \%$ van $€ 10.000$. Zo toont het CPB aan dat de top $10 \%$-vermogenden bijdraagt aan $90 \%$ van het totaal aan belastingopbrengsten in box 3. Deze draagkracht is echter niet terug te brengen op microniveau. Vergelijk immers het progressieve tarief in box 1, waarbij elke persoon naast een relatief hoger belastbaar bedrag ook een relatief hoger tarief kent. Omdat de wetgever voor een rechtvaardige belasting moet kijken naar werking op microniveau, wordt box 3 strijdig geacht met het draagkrachtbeginsel (Van der Geld, 2006, p. 4). Dit draagkrachtbeginsel is juist fundamenteel voor een rechtvaardige belasting.

\subsection{Draagkracht}

Waarom draagkracht zo fundamenteel is, is uit te leggen met filosofische onderbouwing. Rawls zegt dat voor het begrijpen van een rechtvaardige samenleving een theoretisch model toegepast moet worden, genaamd de sluier der onwetendheid (Rawls, 1971, pp. 10-13; Hausman \& McPherson, 1993, p. 710; Sugin, 1997, pp. 2009-2010). Achter deze fictieve sluier zijn alle burgers volledig vrij van informatie omtrent zichzelf en anderen. Geen enkele burger weet zijn individuele status, zoals geslacht, vermogen, sociale status, beroep etc. Iedereen is dus blanco en gelijk, maar weet wel dat sprake is van een bepaalde klasse-indeling (b.v. mannen en vrouwen bestaan, er is rijkdom en armoede). De burgers zijn tevens vrij om te handelen naar wat juist lijkt volgens hen. De burgers onderhandelen voor beginselen en instituties van hun samenleving, en de uitkomsten zijn als rechtvaardig te beschouwen omdat iedereen ze accepteert in een positie van volledige gelijkheid en vrijheid. Draagkracht is achter deze sluier als rechtvaardig te beschouwen, omdat burgers achter een sluier der onwetendheid logischerwijs tot een draagkrachtprincipe komen. De minst bedeelden zijn achter de sluier der onwetendheid degenen wiens positie verbeterd moet worden. Immers, alle posities anders dan de minst bedeelden zijn beter en men wil voor zichzelf een zo goed mogelijke positie verzekeren, gegeven dat men niet weet waar ze gaat eindigen in de 'echte' wereld. Teneinde een zo goed mogelijke positie voor henzelf te verzekeren, laten burgers de sterkste schouders de zwaarste lasten dragen, ter bevoordeling van de minst bedeelden. Hoewel burgers ook willen dat eigen prestaties en kunde voor een goede beloning zorgen, lijkt enige vorm van draagkracht dus rechtvaardig, omdat het de uitkomst is die gekozen wordt in vrije onderhandelingen tussen volledig gelijke (namelijk blanco) personen. Rawls onderstreept dat dit beginsel niet tot volledige gelijkheid hoeft te worden doorgetrokken. Indien een mate van ongelijkheid ervoor zorgt dat de onderste bevolkingsgroepen er beter vanaf komen dan in een positie van volledige gelijkheid, is de ongelijkheid als rechtvaardig te beschouwen. Echter is dat in de huidige vermogensongelijkheid niet het geval. De rijken worden rijker en de armen armer; vermogensongelijkheid leidt door verlaagde economische groei voor een verlaagde welvaart van de minst bedeelden (Broers, 2014, p. 98; Kremer et al., 2014 , p. 95). Het is dan aan het fiscale systeem om terug te vallen op draagkracht en rechtvaardige belastingwetten te vormen.

\subsection{Het nieuwe Belastingplan}

De alternatieven voor box 3 zijn divers. De staatssecretaris stelt per ingang van 1 januari 2017 voor om vermogen te belasten naar een gemiddelde vermogensverdeling, op basis van verschillende gemiddelde forfaitaire rendementen van enerzijds spaargeld en anderzijds beleggingen (de vermogensmix) (Brief van de staatssecretaris van Financiën, Tweede Kamer, 19 juni 2015, p. 3; Belastingplan 2016, 2015, pp. 10-15). Het huidige voorstel oppert een forfaitair rendement van $1,63 \%$ voor spaarekeningen en $5,5 \%$ voor beleggingen (totaal van panden, aandelen et cetera). Deze percentages zouden elk jaar worden aangepast op basis van de laatste historische rendementsgegevens. Dit is in lijn met andere voorstellen. Zo opperen Boer en Vording (2015, p. 7) om een fictief rendement naar type vermogen te hanteren, bijvoorbeeld $2 \%$ voor spaarrekeningen en $4 \%$ voor aandelen. Volgens de staatssecretaris sluit het nieuwe voorstel beter aan bij de realiteit. Zoals eerder bleek lopen de rendementen van verschillende bestanddelen sterk uiteen, dus in dat opzicht is het voorstel van de staatssecretaris zeer wenselijk. Er zit echter een aantal haken en ogen aan dit (nog in de kinderschoenen staande) voorstel. Hoewel een stap in de goede richting, bestaat ten eerste nog steeds het probleem met de forfaitaire werking, mede door de versimpelde tweedeling tussen spaarrekeningen en het vrij brede begrip beleggingen. De staatssecretaris stelt een 
forfaitair gemiddelde voor gebaseerd op de meest actuele beschikbare gegevens. Dit werkt onzes inziens wel gunstig voor de kleine spaarder gezien de geringe rendementsfluctuaties, maar de grote belegger zal nog steeds voordeel trekken uit het forfaitaire systeem wegens middeling van het rendement. De tweede en meest fundamentele opmerking heeft te maken met de redenatie voor deze specifieke belastinghervorming. Voor de kern van het box 3-stelsel is gekozen voor een "evenwicht ... tussen eenvoud, uitvoerbaarheid en rechtvaardigheid", zo herhaalt de staatssecretaris. Rechtvaardigheid wordt verder echter niet verduidelijkt, en hoewel het nieuwe Belastingplan wel degelijk verbeterde realiteitsbeantwoording aanbiedt, lijkt teruggrijping op termen als rechtvaardigheid zonder nodige verduidelijking. We zijn te spreken over de stap richting meer realiteit, hetgeen de nieuwe box 3 sterk omarmt. Onzes inziens ligt een rechtvaardige vermogensbelasting in het licht van vermogensongelijkheid echter in de draagkracht en lijkt verdere belastinghervorming nodig. Wij raden naast de optie van de staatssecretaris belangrijke alternatieven voor box 3 aan, namelijk een progressief tarief en/of een vermogenswinstbelasting.

\subsection{Progressief tarief}

Dat een progressief tarief uit overweging van draagkracht verdedigbaar is, moge duidelijk zijn. In het licht van vermogensongelijkheid is een progressief tarief echter nog sterker verdedigbaar volgens Piketty. De progressiviteit van de top, los van het proportionele tarief waaraan de meesten onderhevig zijn, bepaalt in sterke mate de ongelijkheid (Piketty, 2014, pp. 495496). Daar wijst ook de geschiedenis op: na het tumult en de Wereldoorlogen tussen 1914 en 1945 lijkt het progressieve tarief op vastgoed te hebben verhinderd dat de ongelijkheid zo onmetelijk hoog steeg als voorheen het geval. Andersom bekeken is duidelijk een correlatie zichtbaar tussen het afschaffen van een sterk progressief tarief en een sterke (inkomens)ongelijkheid in de Verenigde Staten en Groot-Brittannië. Om het argument dichter bij huis te brengen, wijst Piketty tevens op de belastingcompetitie tussen Europese landen, dat leidt tot afzwakking van het overkoepelende systeem en een stijging van vermogensongelijkheid in heel Europa als gevolg. Als Nederland vermogensongelijkheid echt tegen wil gaan, moeten de hogere vermogens door middel van een progressief tarief zwaarder worden belast. Daarom is als alternatief voor of zelfs ter aanvulling van een vermogenswinstbelasting ook een progressief tarief in box 3 wenselijk, vanaf $30 \%$ zoals al geldend, maar oplopend tot bijvoorbeeld 50\% vanaf $€ 500.000$ aan privévermogen (Boer $\&$ Vording, 2015 , p. 7). Deze oplossing is voor vermogensongelijkheid aantrekkelijk, kan zich al beter houden aan het draagkrachtbeginsel en is niet extra gevoelig voor ar- bitrage. Het is daarom jammer dat de staatssecretaris van mening is dat het vlakke $30 \%$-tarief ongewijzigd moet worden gelaten. Tevens is volstrekt onduidelijk waarom een progressief tarief niet in overweging is genomen en het is opmerkelijk dat de staatssecretaris hier in het nieuwe Belastingplan niet op ingaat. Een progressief tarief verhindert volgens ons namelijk niet de hoog in het vaandel staande mix van eenvoud, uitvoerbaarheid en rechtvaardigheid. Het staat immers vast dat de top- vermogenden een hoger rendement halen dan de huidige rendementsfictie van $4 \%$, zoals ook de staatssecretatris aangeeft. Als vermogensongelijkheid echter als onwenselijk wordt ervaren, is voor een oplossing belangrijk hoeveel van dat rendement wordt belast.

\subsection{Vermogenswinstbelasting}

Een vermogenswinstbelasting is evenzeer verdedigbaar vanuit het oogpunt van draagkracht (Herreveld, 1999, p. 2; Boer $\&$ Vording, 2015, p. 6). Een vermogenswinstbelasting heft over het totaal van alle inkomsten verkregen uit een vermogensbron en de waardestijging van de vermogensbron zelf. Een vermogenswinstbelasting voldoet aan het draagkrachtbeginsel gezien de hoogste vermogenswinsten tegen een relatief hoog belastingtarief worden belast, gelijk aan de inkomstenbelasting in box 1 . Ook houdt een progressief vermogenswinstbelastingsysteem rekening met de verschillende rendementen op soorten vermogen, want hogere rendementen leiden simpelweg tot een hogere tariefschijf. De reden tot verandering lijkt met de groeiende vermogensongelijkheid en het argument van rechtvaardige draagkracht wel te ontstaan. De staatssecretaris lijkt de mening te delen dat de wijze van vermogensbelasting een rechtvaardigheidsgrond moet hebben, hoe verdedigbaar de werking ook op papier (Kamerstukken II 2014/15, p. 22). Echter lijkt de rechtvaardigheidskwestie in het nieuwe Belastingplan vergeten te zijn ten koste van de eerder genoemde realiteit en uitvoerbaarheid; de vermogenswinstbelasting is doelmatig gezien te complex en wordt daarom afgewezen. Hoewel het begrijpelijk is dat een systematische omschakeling ingewikkeld is en de nodige kosten met zich meebrengt, zoals in het Belastingplan wordt beargumenteerd, is het toch wenselijk een rechtvaardige vermogenswinstbelasting na te streven. Wij zijn tevreden met de welwillendheid van de staatssecretaris om periodiek te blijven controleren in hoeverre dit mogelijk is, maar sporen wel aan om nu al onderzoek in te stellen naar de mogelijkheden van het vermogenswinstbelastingsysteem. Met wachten blijft de omschakeling immers complex.

\subsection{Kapitaalvlucht en eenvoud}

Een mogelijke keerzijde van zowel een progressief tarief als een vermogenswinstbelasting is de invloed op 
kapitaalvlucht van box 3 naar (buitenlands) BV-vermogen (zie bijvoorbeeld Van Dam, 2005 en Van Koningsveld, 2015). Zoals eerder aangegeven is de vermogensongelijkheid van zulk scheef niveau deels te wijten aan de globalisatie en de vermogensflexibiliteit. In het kader van belastingontwijking en belastingparadijzen is dit een sterk argument tegen de mogelijk gedragsverstorende werking van progressiviteit en vermogenswinstbelasting. Zo toont Zucman (2013, p. 1321, 1348) aan dat ongeveer $8 \%$ van al het financieel privévermogen van de V.S. en rijke EU-landen (waaronder ook Nederland valt) wordt gehouden in belastingparadijzen. Om zekerheid en cijfermatige duidelijkheid over de mogelijke kapitaalvlucht te geven is echter fiscale transparantie noodzakelijk, en fiscale internationale coördinatie en coöperatie is daarom raadzaam. ${ }^{6}$ Er ontstaat echter steeds meer afbrokkeling van het bankgeheim en een aanhoudende speurtocht voor belastingontduiking, hetgeen de optie voor een progressief tarief op vermogenswinstbelasting ons nog steeds een sterk verdedigbaar alternatief lijkt. ${ }^{7}$ Voor de hoogte van progressieve tarieven, werkelijke uitwerking en invloed op kapitaalvlucht is daarom vervolgonderzoek nodig.

\section{De bedrijfsopvolgingsregeling}

\subsection{Een schijnbaar denivellerende werking}

Ook de bedrijfsopvolgingsregeling in de Successiewet krijgt veel kritiek. Met name is de vraag of bevoordeling van nagelaten ondernemingsvermogen ten opzichte van nagelaten privévermogen niet in strijd is met het gelijkheidsbeginsel, gecodificeerd in onze Grondwet en het Europees Verdrag voor de Rechten van de Mens (Hoogwout, 2012, p. 2). Deze discussie is wederom terug te voeren naar de Rawlsiaanse sluier der onwetendheid en het recht op gelijke kansen. Hoewel deze discussie interessant is voor beschouwing van de regeling in het algemeen, is voor vermogensongelijkheid relevanter wat de verdeling van het ondernemingsvermogen is. Dit vermogen kan immers de facto met de aanzienlijke vrijstelling van $100 \%$ dan wel $83 \%$ worden overgedragen. Wij volgen hierin Albert (2012, p. 2), met de stelling dat de BOR de jure mogelijk wel, mogelijk niet discriminerend is, maar hoe dan ook de facto discrimineert ten gunste van ondernemingsvermogen. ${ }^{8}$ In het teken van vermogensongelijkheid is het relevant hoe de BOR discrimineert, omdat zij overerving van (ondernemings)vermogen versoepelt. Wie dit ondernemingsvermogen relatief in meerdere mate bezit, laat zien aan hoe de BOR vermogen verdeelt.

Het nagelaten ondernemingsvermogen is volgens gegevens van het CBS bijna $10 \%$ van al het nagelaten vermogen. Als gekeken wordt naar wie het ondernemingsvermogen voornamelijk bezit, en in lijn daarmee dus doorgeeft, is het volgende te zien. Van de 33,1 miljard euro aan totaal ondernemingsvermogen in 2011, het laatst gemeten jaar, bezit de top 10\%-vermogenden welgeteld 28,2 miljard euro (CBS Statline 2015). Dit is $85 \%$ van het geheel. Met het oog op al het nagelaten privévermogen zien wij weliswaar dat ook een scheve verdeling heerst, maar deze scheefheid is vergelijkbaar met de algemene vermogensongelijkheid in Nederland. ${ }^{9}$ De ondernemingsvermogensongelijkheid is echter 20 procentpunt hoger dan de al zeer scheve privévermogensongelijkheid. De onderste $10 \%$-vermogensbezitters hebben -3,9 miljard euro aan ondernemingsvermogen, oftewel meer schulden dan bezittingen. Zij hebben dus in geen enkele zin profijt van de BOR. Sterker nog: de onderste $40 \%$ van de vermogensgroepen heeft gemiddeld geen positief ondernemingsvermogen, en heeft geen baat bij een vrijstelling van $100 \%$ dan wel $83 \%$. In relatie tot het totale vermogen speelt ondernemingsvermogen tevens een meer prominente rol voor de meest vermogenden. Voor de top $10 \%$ geldt dat hun ondernemingsvermogen $3,4 \%$ van hun totale vermogen bedraagt. Voor de onderste $10 \%$ is de bijdrage $-2,8 \%$. Oplopend tot $80 \%$ van de vermogensgroepen komt het ondernemingsvermogen in relatie tot hun totale vermogen niet eens boven de $1 \%$ uit.

Hoewel bij deze verdeling geen normatieve claims hoeven te worden geplaatst - dit kan overigens gemakkelijk - is frappant hoe de BOR zich in werkelijkheid uit. Voornamelijk de topvermogens genieten van de BOR. Dit in tegenstelling tot wel $40 \%$ van de onderste vermogens die er geen voordeel uit halen. Wat nog frappanter is, is dat de literatuur zwijgt over deze (volgens CBS-gegevens schijnbaar) denivellerende werking van de BOR. ${ }^{10}$ De discussie wordt voornamelijk geleid door wetmatige ongelijke behandeling. Met het oog op vermogensongelijkheid speelt de werkelijke ongelijke behandeling echter een belangrijke rol. Vervolgonderzoek naar de relatie tussen de BOR en vermogensongelijkheid is derhalve gewenst.

\subsection{Noodzaak van de bedrijfsopvolgingsregeling}

De wetgever onderbouwt de bedrijfsopvolgingsregeling met het feit dat reële bedrijvigheid van ondernemingen gewenst is voor economische groei en maatschappelijke welvaart (Kamerstukken II 2008/09, p. 4). Betaling van successierechten bij erving zou (door liquiditeitsafwezigheid) de continuïteit van de onderneming in gevaar kunnen brengen. Deze ratio is in beginsel terecht. Aanwezigheid van reële bedrijvigheid is een belangrijk aspect van beleid, gezien het zorgt voor werkgelegenheid, economische diversiteit, economische efficiëntie, procesinnovaties en stimulering van andere startende ondernemingen (Beer, 2007, p. 6; Van Praag, 2010, p. 2). Daarentegen schiet de BOR haar doel voorbij als zij niet noodzakelijk is voor bedrijvigheid. Immers, dan genieten verkrijgers van ondernemingen een onnodige vrijstelling. Met empirisch onderzoek toont Hoogeveen $(2012$, pp. 27, 28) aan dat in 
iets meer dan $30 \%$ van de BOR-gevallen sprake is van onvoldoende vrije middelen. Dit is volgens haar geen voldoende rechtvaardiging voor een zo hoge vrijstelling van alle gevallen. Vervolgens heeft de verkrijger in ongeveer $44 \%$ van de gevallen zelf genoeg liquide middelen. Zo bezien heeft bijna $70 \%$ van de nagelaten ondernemingen die onder de BOR vallen een cadeau-effect: de verschuldigde successierechten kunnen gewoon uit de nalatenschap worden betaald en behoeven geen vrijstelling. Voor de overige $30 \%$ geldt dat $44 \%$ van de verkrijgers de successierechten zelf kan betalen. Neem hier het feit mee dat $85 \%$ van het ondernemingsvermogen in handen is van de top $10 \%$, en het lijkt vreemd dat de BOR überhaupt nog bestaat.

\subsection{Kredietfaciliteit}

In het licht van de denivellerende werking van de BOR en de niet voldoende noodzaak is wijziging gewenst. De BOR dient in het teken van rechtvaardigheid te worden afschaft. In het licht van rechtvaardigheid en doelmatigheid kan daarom beter een kredietfaciliteit worden ingevoerd (Hoogeveen 2012, p. 32). Een kredietfaciliteit verschaft ondernemingen met liquiditeitsproblemen financiering voor het betalen van hun successierechten. Dit is doelmatig omdat het financieringsprobleem direct wordt aangepakt en omdat in tegenstelling tot de BOR, een kredietfaciliteit niet verder ingrijpt dan noodzakelijk. Een kredietfaciliteit is rechtvaardig, omdat discriminatie naar soort vermogen wordt verzacht. Immers ontstaat geen direct onderscheid tussen ondernemingsvermogen en privévermogen, beide soorten moeten in beginsel successierechten afdragen. Het enige onderscheid is dat ondernemingen voortzetting behoeven. Enkel in die gevallen is het rechtvaardig en tevens doelmatig dat de overheid steun biedt.

\section{Conclusie en discussie}

De vermogensongelijkheid in Nederland is zeer scheef en problematisch voor economie en politiek. Verstoringen van economische groei zijn onwenselijk en economische machtsconcentratie leidt tot problemen voor politieke besluitvorming, politieke participatie en algemeen vertrouwen in politiek. De fiscaliteit speelt in dit geheel van problemen een belangrijke rol. Niet enkel omdat de fiscale wetgeving doelmatig is, maar juist omdat zij een rechtvaardig karakter behelst. Zij is immers de institutie die burgers steunt in een rechtvaardige samenleving.

De forfaitaire werking van box 3 is allesbehalve rechtvaardig en versterkt vermogensongelijkheid. Dit artikel laat zien dat voornamelijk rendementen op spaarrekeningen de afgelopen decennia niet beantwoorden aan het forfait van $4 \%$. Dit ten nadele van spaarders onderaan de vermogensgroepen. Echter ligt de onrechtvaardigheid van box 3 dieper. Box 3 is in het hui- dige systeem inherent onrechtvaardig, omdat huishoudens met hoge vermogens en hogere rendementen een relatief lagere belastingdruk genieten. Draagkracht is als rechtvaardig te begrijpen, omdat in een positie van volledige vrijheid en gelijkheid, burgers onderling afspreken om de sterkste schouders de zwaarste lasten te laten dragen. De minst bedeelden in de samenleving komt dit immers ten goede.

Het nieuwe Belastingplan heeft goede verbeteringen op het gebied van draagkrachtkritiek. Het hanteren van verschillende forfaitaire rendementen voor spaargeld en beleggingen beantwoordt aan de realiteit bij het halen van structureel hogere rendementen op beleggingen. Het forfaitaire rendement blijft echter gevoelig voor kritiek, gezien sterke rendementuitschieters naar boven voordeel blijven halen, hetgeen vermogensongelijkheid aan de top versterkt. Een onderbouwde rechtvaardigheidsgrond, welke de staatssecretaris niet biedt, is gelegen in draagkracht en biedt alternatieven.

Betere alternatieven liggen in het voeren van een progressief tarief, een vermogenswinstbelasting of eventueel een combinatie van beide. Deze alternatieven beantwoorden aan draagkracht. Verder zijn zij een zeer goed alternatief in het tegengaan van de vermogensongelijkheid, gezien zij de hoogste vermogens rechtvaardiger belasten. Wel zijn beide alternatieven mogelijk onderhevig aan kapitaalvlucht naar BV's of naar het buitenland. Verder onderzoek dient deze invloeden aan te tonen.

Tot slot de bedrijfsopvolgingsregeling. De BOR lijkt de facto denivellerend te werken, oftewel de topvermogens te bevoordelen. Hoewel de mening wordt gedeeld dat ondernemingen continuiteit behoeven, lijkt in het teken van vermogensongelijkheid de werking frappant en tevens te vergaand. Het is jammer dat de literatuur dit verband nog niet onderkent en vervolgonderzoek naar de de facto denivellerende werking is gewenst. Het is overigens aantoonbaar dat in de meeste gevallen de BOR niet noodzakelijk is voor continuïteit van de onderneming. In die zin lijkt een kredietfaciliteit rechtvaardiger en doelmatiger.

D.L. Hwan is student fiscale economie aan de Universiteit van Amsterdam.

J.A. de Vries MSc RA is werkzaam bij de Belastingdienst en verbonden aan de sectie fiscale economie van de Universiteit van Amsterdam. Zij schrijft dit artikel op persoonlijke titel. 
Piketty's r > g. In Capital in The Twenty-First Century laat Piketty zien hoe het rendement op vermogen de afgelopen tijd (aanzienlijk) hoger is geweest dan de economische groei in verschillende landen. Volgens deze formule leidt vermogensongelijkheid in een vicieuze cirkel tot nog meer vermogensongelijkheid. Een situatie waarin het rendement op vermogen relatief groter is dan de economische groei, betekent immers dat de vermogende mensen jaarlijks meer binnen krijgen dan dat de werkende mensen extra aan loon bijverdienen (Piketty, 2014, pp. 353-354).

2. De Gini-coëfficiënt is een cijfer tussen 0 en 1, waarbij 0 aangeeft dat iedereen precies evenveel heeft en een Gini-coëfficiënt van 1 betekent dat al het bezit in handen is van één persoon. Voor Nederlandse cilfers, zie Van Bavel \& Frankema, 2013, p. 16.
OECD 2014, p. 1. Voor analogie met vermogensongelijkheid zie: Van Bavel in Kremer et al. 2014, p. 90.

4. Zie naast Apeldoorn et al. (2015): Gribnau (2012) en Dusarduijn (2013).

5. Overigens is het in Nederland na herziening nog gemakkelijker geworden vermogen tegen weinig belasting na te laten. Blijkens gegevens van het Ministerie van Financiën en het CBS is sinds de tariefverlaging in 2010 het nagelaten vermogen gegroeid met 40\%. Dit in tegenstelling tot de erfbelastingopbrengsten, die gelijk zijin gebleven aan de opbrengsten voor herziening. Zo lijkt na herziening de versoepelde doorgeefvrijheid de vermogensongelijkheid over generaties in de hand te werken. Wegens omvang van dit artikel is uitgebreide behandeling niet mogelijk. Zie: Ministerie van Financiën. (2012) en gegevens CBS.
Ook een van de meest prominente claims en aansporingen van Piketty.

7 Denk bijvoorbeeld aan de recente afbrokkeling van de Zwitserse banken en voor het tegengaan van belastingontwijking, zie ook het recentelijke arrest van de Hoge Raad 5 juni 2015, nr. 13/00343.

Z Zie voor wel discriminerend: Rb. Breda 13 juli 2012, LJN BX3386 en voor niet discriminerend: Rb. Arnhem 25 maart 2010, LJN BX0548 en Hof Den Haag 11 februari 2014, AWB 12/11465.

9. Namelijk met de top 10\% in bezit van $70 \%$ in 2011 en de top 3\% ongeveer 30\%.

10 Alleen Wijtvliet suggereert in een recente workshop dat de bedrijfsopvolgingsfaciliteiten vermogensongelijkheid kunnen versterken. In: Van Apeldoorn et al., 2015, p. 6.

\section{Literatuur}

- Albert, P.G.H. (2012). Gelijk zijn, gelijk hebben en gelijk krijgen. Weekblad Fiscaal Recht, 2012/1214.

- Apeldoorn, L.C.J. van, Gribnau, J.L.M., \& Verbeek, B. (2015). Rechtvaardigheid en belastingen - filosofie en fiscaliteit. Weekblad Fiscaal Recht, 2015/7085, 93-103.

- Bavel, B. van, \& Frankema, E. (2013). Low income inequality, high wealth inequality. The puzzle of the Rhineland welfare states. Centre for Global Economic History. Universiteit Utrecht: Working paper no. 50.

- Bavel, B. van, \& Salverda, W. (1999). Vermogensongelijkheid in Nederland. Economisch Statistische Berichten, 99, 392-395.

- Beer, P.T. de. (2007). De belaste dood: belastingheffing op erfenissen. In: Caminada, C.L.J., Haberham, A.M., Hoogteilling, J.H., \& Vording, H. (editors). Belasting met beleid, (pp. 291-302). Den Haag: Sdu uitgevers.

- Belastingplan 2016. (2015). Wijziging van enkele belastingwetten en enige andere wetten. Geraadpleegd op https://wwww.rijksoverheid.n//documenten/kamerstukken/2015/09/15/belastingplan-2016.

- Boer, J.P., \& Vording, H. (2015). Keuzes voor een betere vermogensrendementsheffing. Weekblad Fiscaal Recht, 2015/7096, 614621.

- Brief van de Staatssecretaris van Financiën, Tweede Kamer, 19 juni 2015, AFP2015/512.
Geraadpleegd op https://www.rij)ksoverheid. n//documenten/kamerstukken/2015/06/19/ belastingherziening.

- Broers, V. (2014). Thomas Piketty's Kapitaal: samengevat in Nederlands perspectief. Amsterdam: Prometheus Bert Bakker.

- CBS Statline. (2015). Samenstelling vermogen; particuliere huishoudens naar kenmerken. Geraadpleegd op: http://statline.cbs.nl/ Statweb/publication/?DM=SLNL\&PA=80056N ED\&D1 $=0-3 \& D 2=0,31,121-130,155$ 164\&D3=0,12\&D4=5\&HDR=T,G2\&STB=G3, G1\&WW=T.

- CBS. (2014). Welvaart in Nederland 2014: Inkomen, bestedingen en vermogen van huishoudens en personen. Den Haag: CBS. Geraadpleegd op http://www.chs.nl/nl--NL/menu/ themas/inkomen-bestedingen/publicaties/ publicaties/archief/2014/2014-welvaart-innederland-pub.htm.

- Commissie van Dijkhuizen. (2013). Naar een activerender belastingstelsel. Commissie inkomstenbelasting en toeslagen, 57-73. Geraadpleegd op https://www.rijksoverheid.n// onderwerpen/inkomstenbelasting/documenten/rapporten/2013/06/18/eindrapport-commissie-inkomstenbelasting.

- Dam, E. van (2005). Beleggen in de bv of in privé? NDFR, 11-6, 18-22. Geraadpleegd op http://www.ndfr.nl/.

- Dusarduijn, S.M.H. (2013). Van Dijkhuizens vermogensrendementheffing. Onafhankelijk Maandblad voor Belastingrecht en Belastingpraktijk, 9, 254-266.

- Floor, E., Groot, S., \& Lejour, A. (2015). Het financieel vermogen in box 3: verdeling en belasting. Den Haag: CPB. Geraadpleegd op http://www.cpb.n//publicatie/het-financieelvermogen-in-box-3-verdeling-en-belasting.

- Geld, J.A.G. van der (2006). De evaluatie van de Wet IB 2001: box 3. Weekblad Fiscaal Recht, 2006/6662, 302-307.

- Gribnau, J.L.M. (2012). Vertrouwen, legitimiteit en belastingen. Symposium Tilburg University, Tilburg.

- Hausman, D.M., \& McPherson, M.S. (1993). Taking ethics seriously: Economics and contemporary moral philosophy. Journal of Economic Literature, 31(2), 671-731.

- Herreveld, F.R. (1999). Vermogensrendementsheffing. Weekblad Fiscaal Recht, 1999/1524, 1-8.

- Hoogeveen, M.J. (2012). Fiscaal bedrijfsopvolgingsbeleid is onder de maat. Tijdschrift voor Fiscaal Ondernemingsrecht, 2012/118, 1-42.

- Hoogwout, T.C. (2012). Bedrijfsopvolging in de Successiewet discriminatoir? Fiscaal Tijdschrift vermogen, 9, 14-20.

- Kamerstukken II, 2008/09, 31 930, nr. 3. Geraadpleegd op https://zoek.officielebekendmakingen.nl/kst-31930-3.html. 
- Kamerstukken II, 2014/15, 32 140, nr. 5. Geraadpleegd op https://zoek.officielebekendmakingen.nl/kst-32140-5.html.

- Koningsveld, T.J. van (2015). De offshore wereld ontmaskerd. Een studie naar aard en omvang van misbruik van offshore vennootschappen door Nederlandse (rechts)personen. Proefschrift Tilburg University. Zeist: Uitgeverii Kerkebosch.

- Kremer, M., Bovens, M., Schrijvers, E., \& Went, R. (2014). Hoe ongelijk is Nederland? Een verkenning van de ontwikkeling en de gevolgen van economische ongelijkheid. Den Haag: Wetenschappelijke Raad voor het Regeringsbeleid. Geraadpleegd op http://www.wrr.n//publicaties/ publicatie/article/hoe-ongelijk-is-nederlandeen-verkenning-van-de-ontwikkeling-en-gevolgen-van-economische-ongelijkhe/
- Ministerie van Financiën (2012). Fiscale kengetallen. Den haag: Ministerie van Financiën.

- Niessen, R.E.C.M. (2000). Een nieuwe belasting op vermogensopbrengst in Nederland. Maastricht: Maastricht University. Geraadpleegd op http://pub. maastrichtuniversity. n1/32a7d855-efa9-47d0-bef3-3a9b51dee166.

- OECD (2014). Does inequality hurt economic growth? Parijs: Organisation for Economic Cooperation and Development. Geraadpleegd op http://www.oecd.org/newsroom/inequalityhurts-economic-growth.htm.

- Piketty, T. (trans. Goldhammer, G). (2014). Capital in the twenty-first century. London: The Belknap Press of Harvard University Press.
- Praag, C.M. van (2010). Fiscaal bevorderen van groei en innovatie via de DGA? Essay voor de Studiecommissie Belastingstelsel (Nan Weeghel) over ondernemerschap en fiscaliteit. - Rawls, J. (1971). A theory of justice. Revised Edition (1999). London: The Belknap Press of Harvard University Press, London.

- Solt, F. (2008). Economic inequality and democratic political engagement. American Journal of Political Science, 52(1), 48-60.

- Sugin, L. (2003). Distributive justice and limitations on taxation: What Rawls demands from tax systems. Fordham Law Review, 72(5), 1991-2014.

- Zucman, G. (2013). The missing wealth of nations: Are Europe and the U.S. net debtors or net creditors. The Quarterly Journal of Economics, 128(3), 1321-1364. 